\title{
Editorial
}

\section{Mejores prácticas para gestionar el conocimiento según la ISO 30401}

Yuber Liliana Rodrígue*-Rojas, Ph.D.

Editora

Profesora Maestría en Calidad y Gestión Integral

Convenio Universidad Santo Tomás-Icontec

Doi: https://doi.org/10.15332/24631140.5090

La Organización Internacional de Normalización (ISO, International Organization for Standardization) publicóen noviembre de 2018 la nueva norma técnica internacional ISO 30401, relacionada con los requisitos de los sistemas de gestión de conocimiento. Esta norma tiene como propósito dar soporte a las organizaciones en el desarrollo de sistemas de gestión que promuevan la eficacia y la creación de valor a través del conocimiento para todas las partes interesadas. Allí se define la gestión del conocimiento como una disciplina enfocada en las formas en que las organizaciones crean y usan el conocimiento.

Este nuevo referente normativo adopta la estructura de alto nivel planteada por la ISO en 2012. Por lo tanto, se estructura en diez capítulos, a saber: alcance, referencias normativas, términos y definiciones, contexto de la organización, liderazgo, planeación, apoyo, operación, evaluación del desempeño y mejora. Al igual que las demás normas que siguen esta estructura mantiene como base para la gestión el ciclo PHVA (planificar, hacer, verificar y actuar a partir del aprendizaje).
De acuerdo con la norma, la gestión del conocimiento es esencial para las organizaciones. Se parte de la comprensión de que el trabajo tiene como objetivo generar resultados valiosos para aquellas a través de la aplicación del conocimiento. Es por ello que la gestión de este se convierte en un camino lógico para identificar, retener, mantener, apropiar y difundir los elementos diferenciadores de una organización. En otras palabras, se convierte en un aspecto clave para la efectividad, el aumento de la colaboración y la competencia.

$\mathrm{Al}$ contar con un sistema de gestión del conocimiento las organizaciones podrán identificar, crear, analizar, representar y distribuir el conocimiento asociado a sus procesos para generar valor. Por ende, podrán dar respuesta de manera rápida a los cambios del entorno. Uno de los requisitos a destacar de esta norma -además del análisis de los factores internos y externos, las necesidades y las expectativas de las partes interesadas-es la creación de la cultura de gestión del conocimiento. Esta es definida en la norma técnica ISO 30401 como los 
elementos de la cultura organizacional que apoyan los valores, los comportamientos y las actividades asociadas al mencionado sistema.

De acuerdo con el anexo $\mathrm{C}$ de la citada norma técnica, la cultura de gestión del conocimiento se refleja en la medida en que las personas:

- Sienten confort al discutir los problemas de la organización y a la vez pueden plantear soluciones.

- Comparten el conocimiento y la información de manera abierta y honesta para socializarlo y difundirlo a través de la organización.

- Protegen el conocimiento de la organización.

- Se sienten empoderados para usar autónomamente el conocimiento.

- Demuestran responsabilidad por su propio aprendizaje y sus resultados.

- Ofrecen su conocimiento a otros en lugar de mantenerlo guardado para ellos mismos.

- Colaboran con sus colegas en lugar de competir con ellos.

- Invierten tiempo en reflexionar y aprender.

- Dan valor a adquirir nuevos conocimientos a través de sus nuevas experiencias (éxitos o fracasos).

Es de destacar que esta norma técnica internacional es un gran avance en los sistemas de gestión del conocimiento, dado que brinda a las organizaciones una orientación sobre cómo generar valor a partir de estos. No obstante, en la academia existen avances investigativos en el campo, los cuales no solo han generado aportes conceptuales, teóricos y metodológicos, sino que cuestionan el futuro de la gestión del conocimiento más allá de la estructura. En este sentido, es imperante dar continuidad a investigaciones en el campo que den cuenta de los impactos de la prospectiva de la gestión del conocimiento en las organizaciones.

Los estudios bibliométricos indican que se ha incrementado la investigación en la gestión del conocimiento. A partir del estudio realizado por Gaviria-Marina, Merigób y Baier-Fuentes (2019) se identificó la relevancia que se le ha dado al tema en los últimos diez años. Además, los investigadores detectaron que el país de mayor influencia en el campo ha sido Estados Unidos. Asimismo, en el estudio de Mardani, Nikoosokhan, Moradi y Doustarb (2018) se evidenció que las actividades de gestión del conocimiento impactan la innovación y el desempeño organizacional directa e indirectamente a través de un aumento en la capacidad de innovación. La creación de conocimiento tiene efectos más significativos en la velocidad, la calidad y la cantidad de la innovación, mientras que la calidad de la innovación, la creación de conocimiento y la integración de este tienen efectos más significativos en el rendimiento organizacional.

Hoy día se menciona que el conocimiento es el activo principal de las organizaciones, y los sistemas que permiten gestionarlo se implementan para darle un manejo adecuado. Sin embargo, una crítica a la innovación en la gestión del conocimiento es el enfoque en los aspectos técnicos y estructurales para el almacenamiento del conocimiento y la poca atención tanto a la motivación de las personas para su intercambio (Friedrich, Becker, Kramer, Wirth y Schneider, s. f.; Shujahat, Sousa, Hussain, Nawaz, Wang y Umer, 2019) como a la prospectiva de la gestión del conocimiento y sus dimensiones cognitivas (Bootz, Durance y Monti, 2019). Al respecto, la norma técnica ISO 30401 hace énfasis en la cultura para la gestión del conocimiento en todas sus fases como un elemento novedoso y diferenciador. 
Algunos de los estudios reportados en la literatura académica presentan diseños de sistemas de gestión del conocimiento orientados a la estrategia empresarial que respalda la supervivencia, la viabilidad y la mejora del proceso de toma de decisiones de gestión a largo plazo, basado en el conocimiento y las experiencias (Córdova y Gutiérrez, 2018; Chouikha y Dhaou, 2018).

Es de destacar que el acceso al conocimiento crea oportunidades para el desarrollo profesional en las organizaciones a través del aprendizaje, la práctica y el intercambio. En este sentido, la investigación debe orientarse no solo a desarrollar estructura para la gestión, sino para la apropiación y el empoderamiento de las personas que conforman una organización en pro de la autogestión del conocimiento y su disposición para la creación de valor y el desarrollo organizacional.

En este sentido, la revista Signos. Investigación en Sistemas de Gestión se creó para difundir el conocimiento derivado de procesos de investigación encaminados a comprender la interacción de los sistemas de gestión en diversas organizaciones y el aporte de estos al conocimiento organizacional. En esta oportunidad, presenta el número 11.2 en el que se describen los resultados de diez investigaciones, a saber:

1. Las competencias científicas a partir de la gestión del conocimiento en instituciones de educación superior.

2. Calidad de vida laboral en trabajadores de la salud en países latinoamericanos: metaanálisis.

3. Evolución del reporteo en sostenibilidad en Latinoamérica bajo los lineamientos del GRI (Global Reporting Initiative).
4. Metodología para la integración de la gestión en una pyme del sector ferretero en Colombia a partir de los modelos SG-SST e ISO 9001.

5. Estrategias para fortalecer el proceso de gestión del talento humano del sistema de gestión de la calidad en una entidad pública.

6. Articulación entre la NTC-ISO 9001:2015 y los lineamientos de acreditación de programas del CNA en Unitrópico.

7. Integración de la gestión de la calidad con las buenas prácticas de manufactura, apoyada en la gestión del riesgo y del conocimiento en tres empresas farmacéuticas de inyectables de Bogotá, D. C.

8. Modelo de organización comunitaria y desarrollo sostenible en Ixtlán de Juárez, Oaxaca.

9. Evaluación de los procesos del área financiera y su articulación con el sistema de gestión de calidad con base en el modelo PEF en una institución de educación superior.

10. Análisis bibliométrico de la revista Signos. Investigación en Sistemas de Gestión, periodo 1996-2016

Los avances investigativos descritos y los aportes de las revisiones enunciadas brindan un acercamiento, basado en elementos teórico-conceptuales y de la praxis, a la comprensión de aspectos asociados a la gestión del conocimiento en las organizaciones y escenarios analizados. Por ende, este número de la revista se constituye en referente para profesionales especializados, consultores, auditores, formadores empresariales, investigadores y profesores universitarios interesados en comprender los sistemas de gestión del conocimiento. 


\section{REFERENCIAS}

Bootz, J. P., Durance, P. y Monti, R. (2019). Foresight and knowledge management. New developments in theory and practice. Technological Forecasting and Social Change, 140, 80-83. https://doi.org/10.1016/j. techfore.2018.12.017

Chouikha, M. y Dhaou, S. (2018). A multi-faceted analysis of knowledge management systems. Procedia Computer Science, 138, 646-654. Doi: https://doi. org/10.1016/j.procs.2018.10.086

Córdova, F. y Gutiérrez, F. (2018). Knowledge management system in service ompanies. Procedia Computer Science, 139, 392-400. Doi: https://doi.org/10.1016/j. procs.2018.10.275

Friedrich, J., Becker, M., Kramer, F., Wirth, M., Schneider, M. (s. f.). Incentive design and gamification for knowledge management. Journal of Business Research. En prensa.

Gaviria-Marina, M., Merigób, J. y Baier-Fuentes, H. (2019). Knowledge management: A global examination based on bibliometric analysis. Technological Forecasting and Social Change, 140, 194-220. Doi: https://doi.org/10.1016/j.techfore.2018.07.006

ISO (International Organization for Standardization) (2018). ISO 30401:2018. Knowledge management systems. Requirements. Ginebra: ISO.

Mardani, A., Nikoosokhan, S., Moradi, M. y Doustarb, M. (2018). The relationship between knowledge management and innovation performance. The Journal of High Technology Management Research, 29(1), 12-26. https://doi.org/10.1016/j.hitech.2018.04.002

Shujahat, M., Sousa, M., Hussain, S., Nawaz, F., Wang, M. y Umer, M. (2019). Translating the impact of knowledge management processes into knowledgebased innovation: The neglected and mediating role of knowledge-worker productivity. Journal of Business Research, 94, 442-450. Doi: https://doi. org/10.1016/j.jbusres.2017.11.001 


\section{Editorial}

\section{Best Knowledge Management Practices according to ISO 30401}

Yuber Liliana Rodrígues-Rojas, Ph.D

Editor

Professor, Master's Degree in Comprehensive Management and Quality

Universidad Santo Tomás-ICONTEC Agreement

The International Organization for Standardization, ISO, published in November 2018 the new international technical standard ISO 30401 related to the requirements of knowledge management systems. This standard is intended to assist organizations in the development of management systems that promote effectiveness and value creation through knowledge for all stockholders. The standard defines knowledge management as a discipline focused on how organizations create and use knowledge.

This new normative reference adopts the high-level structure proposed by ISO in 2012; therefore, it is divided into 10 chapters, namely: scope, normative references, terms and definitions, context of the organization, leadership, planning, support, operation, performance evaluation, and improvement. Like the other standards that follow this structure, this standard is based on the PDCA (Plan Do, Check, Act from learning) cycle.

According to the standard, knowledge management is essential to organizations. The starting point is understanding that work is aimed at generating valuable results for the organization, which result from the application of knowledge; therefore, knowledge management becomes a logical way to identify, retain, maintain, appropriate, and disseminate the differentiating elements of the organization; that is, it becomes a key aspect to effectiveness, increased collaboration and competence.

By having a knowledge management system, organizations will be able to identify, create, analyze, represent and distribute knowledge associated with their processes to generate organizational value; therefore, they will be able to swiftly respond to changes in their environment. One of the requirements of this standard that is worth highlighting, in addition to the analysis of the internal and external factors, needs and expectations of the stockholders, is the creation of the knowledge management culture, which is defined in the ISO 30401 technical standard as one of the elements of organizational culture that support values, behaviors and activities associated with the knowledge management system.

According to Annex Cof the abovementioned technical standard, the knowledge management culture reflects the extent to which people: 
- Feel comfortable openly discussing issues and offering solutions

- Share knowledge and information openly and honestly to enhance socialization and flow of knowledge through the organization

- Protect organizational knowledge

- Feel empowered to autonomously act on knowledge

- Demonstrate accountability for their own learning and results

- Offer their knowledge to others rather than keeping it to themselves

- Collaborate with, rather than compete with, their colleagues

- Invest time in reflecting and learning

- Place value on acquiring new knowledge through their own experiences (success or failure)

It is worth highlighting that this international technical standard is a breakthrough on knowledge management systems, since it provides organizations with guidance on value generation from knowledge management; notwithstanding, academic research works in this area have made significant progress, because they not only have generated conceptual, theoretical and methodological contributions, but also are questioning about the future of knowledge management beyond structure. In this regard, it is important to continue with the research efforts in the area, which deal with the impacts of knowledge management prospective in organizations.

Bibliometric studies suggest that research in knowledge management has increased. Based on the study by
Gaviria-Marina, Merigób and Baier-Fuentes (2019), it was possible to identify the relevance this topic has had over the last 10 years; furthermore, researchers detected that the most influential country in this field has been the United States. Likewise, the study by Mardani, Nikoosokhan, Moradi and Doustarb (2018) evidenced that knowledge management activities directly impact innovation and organizational performance and indirectly through an increase in innovation capacity. The creation of knowledge has more significant effects on velocity, quality and quantity of innovation, whereas innovation quality, knowledge creation and knowledge integration have more significant effects on organizational performance.

Today, it is said that knowledge is the main asset of organizations and that knowledge management systems are implemented to properly manage this resource; however, a criticism to innovation in knowledge management is the approach to the technical and structural knowledge storage aspects and the little attention paid to motivating people to exchange knowledge (Friedricha, Beckera, Kramerb, Wirthb and Schneider, s.f; Shujahat, Sousa, Hussain, Nawaz, Wang and Umer, 2019) and in the prospective of knowledge management and its cognitive dimensions (Bootz, Durance and Monti 2019). In this regard, the technical standard ISO 30401 emphasizes knowledge management culture in all its phases as an innovative and differentiating element.

Some of the studies reported in the academic literature present knowledge management systems oriented toward the business strategy that supports survival, viability and improvement of the decision-making process of long-term management, based on knowledge and experience (Córdova, F. y Gutiérrez, 2018; Chouikha, M. and Dhaou, S, 2018).

It is worth highlighting that access to knowledge creates opportunities for professional development in 
organizations through learning, practice and exchange. In this regard, research should be oriented not only toward developing structure for management but also toward appropriation and empowering of people composing an organization, in favor of knowledge self-management and their willingness for value creation and organizational development.

In this sense, the magazine SIGNOS- investigacion en sistemas de gestion was created to disseminate knowledge derived from research processes intended to understand the interaction of the management systems in different organizations and their contribution to organizational knowledge. In this opportunity, the magazine presents its number 11.2, in which the results of 10 research works pare published, namely

1. Scientific competences based on knowledge management in Higher Education Institutions

2. Quality of working life in health workers in Latin American countries: a meta-analysis

3. Evolution of sustainability reporting in Latin America under the guidelines of the Global Reporting Initiative (GRI)

4. Methodology for management integration in a medium-sized enterprise in the hardware sector in Colombia, based on the SG-SST and ISO 9001 models

5. Strategies to strengthen the human talent management process of the quality management system in a public entity

6. Articulation between NTC - ISO 9001:2015 and the program accreditation guidelines of $\mathrm{CNA}$ in Unitrópico
7. Integration of quality management with good manufacturing practices, based on risk and knowledge management in three pharmaceutical firms producing products for injection in Bogota, D.C.

8. Community organization model and sustainable development in Ixtlán de Juárez, Oaxaca

9. Assessment of financial processes and their articulation with the quality management system based on the PAF model in a Higher Education Institution

10. Bibliometric analysis of magazine Signos - investigación en sistemas de gestión from 1996-2016

The research progress described above, and the contributions of the reviews listed provide an approach from theoretical, conceptual elements and praxis in the understanding of those aspects associated with knowledge management in organizations and scenarios analyzed; therefore, this number of the magazine becomes a benchmark for specialized professionals, consultants, auditors, corporate educators, researchers and university professors interested in understanding knowledge management systems.

\section{REFERENCES}

Bootz, JP., Durance, P. y Monti, R. (2019). Foresight and knowledge management. New developments in theory and practice. Technological Forecasting and Social Change, 140, 80-83. https://doi.org/10.1016/j. techfore.2018.12.017

Chouikha, M. y Dhaou, S. (2018). A Multi-Faceted Analysis of Knowledge Management Systems, Procedia Computer Science, 138, 646-654. https://doi. org/10.1016/j.procs.2018.10.086 
Córdova, F. y Gutiérrez, F. (2018). Knowledge Management System in Service Companies, Procedia Computer Science, 139, 392-400. https://doi.org/10.1016/j. procs.2018.10.275

Friedricha, J., Beckera, M., Kramerb, F., Wirthb, M., Schneider, M. (s.f). Incentive design and gamification for knowledge management. Journal of Business Research. Article in press.

Gaviria-Marina, M., Merigób, J., Baier-Fuentes, H. (2019). Knowledge management: A global examination based on bibliometric analysis. Technological Forecasting and Social Change, 140, 194-220. https:// doi.org/10.1016/j.techfore.2018.07.006

International Organization for Standardization, -ISO. (2018). ISO 30401:2018. Knowledge management systems - Requirements. Ginebra: ISO.
Mardani, A., Nikoosokhan, S., Moradi, M. y Doustarb, M. (2018). The Relationship Between Knowledge Management and Innovation Performance. The Journal of High Technology Management Research, 29 (1), 12-26. https://doi.org/10.1016/j.hitech.2018.04.002

Shujahat, M., Sousa, M., Hussain, S., Nawaz, F., Wang, M. y Umer, M. (2019). Translating the impact of knowledge management processes into knowledgebased innovation: The neglected and mediating role of knowledge-worker productivity, Journal of Business Research, 94, 442-450. https://doi. org/10.1016/j.jbusres.2017.11.001. 


\section{Editorial}

\section{Melhores práticas para a gestão do conhecimento conforme a norma ISO 30401}

Yuber Liliana Rodríguew-Rojas, Ph.D.

Editora

Professora do mestrado em qualidade e gestão integral

Convênio Universidad Santo Tomás-ICONTEC

A Organização Internacional de Normalização (International Organization for Standardization, -ISOpor suas siglas em inglês) lançou em novembro de 2018 a nova norma técnica internacional ISO 30401 relativa aos requisitos dos sistemas de gestão do conhecimento. Esta norma pretende auxiliar às organizações no desenvolvimento de sistemas de gestão promovendo a eficácia e a criação de valor para todas as partes envolvidas através do conhecimento. A gestão do conhecimento é definida, nessa norma, como uma disciplina focada nas formas de criação e uso do conhecimento pelas organizações.

Essa nova referência normativa adota a estrutura de alto nível colocada pela ISO em 2012, portanto, estruturase em 10 capítulos, nomeadamente: escopo, referencias normativas, termos e definições, contexto da organização, liderança, planejamento, suporte, operação, avaliação do desempenho e melhora. Assim como as outras normas que acompanham esta estrutura, ela mantém como base para a gestão o ciclo PHVA (Planejar, Fazer, Verificar e Agir a partir do aprendizado).

Conforme a norma, a gestão do conhecimento é essencial para as organizações. A base é a compreensão de que 0 trabalho tem 0 intuito de gerar resultados valiosos para a organização, que resultam da aplicação do conhecimento, épor isso que a gestão do conhecimento se torna o percurso lógico para identificar, reter, manter, apropriar e divulgar os elementos diferenciadores da organização, dito de outra forma, torna-se um aspecto chave para a efetividade, 0 aumento da colaboração e a competência.

Tendo um sistema de gestão do conhecimento, as organizações poderão identificar, criar, analisar, representar e distribuir o conhecimento associado a seus processos para gerar valor organizacional, portanto, poderão responder rapidamente às alterações do ambiente. Para além da análise dos fatores internos e externos, as necessidades e expectativas das partes interessadas, um dos requisitos destacáveis desta norma é a criação da cultura da gestão do conhecimento. Essa cultura define-se na norma técnica ISO 30401 como os elementos da cultura organizacional que assentam os valores, os comportamentos e atividades associadas ao sistema de gestão do conhecimento.

Conforme o Anexo $\mathrm{C}$ da referida norma técnica, a cultura de gestão do conhecimento é refletida na medida em que as pessoas: 
- Sentem conforto tratando os problemas da organização e, por sua vez, podem colocar soluções.

- Dividem o conhecimento e as informações de forma aberta e sincera para seu esclarecimento e divulgação através da organização.

- Protegem o conhecimento da organização.

- Sentem o poder para utilizar o conhecimento de forma autônoma.

- Demonstram responsabilidade pelo próprio aprendizado e resultados.

- Disponibilizam o seu conhecimento aos outros em vez de mantê-lo oculto para si próprio.

- Contribuem com seus colegas em vez de concorrer com eles.

- Investem tempo para a reflexão e o aprendizado.

- Destacam a aquisição de novos conhecimentos através de suas novas experiências (sucessos e fracassos).

É de salientar que esta norma técnica internacional é um grande avanço dentro dos sistemas de gestão do conhecimento, porque disponibiliza às organizações uma diretriz sobre como gerir valor partindo da gestão do conhecimento, no entanto, existem avanços em pesquisas acadêmicas nesse âmbito que não apenas geraram contribuições conceituais, teóricos e metodológicos, mas também estão sendo questionados sobre o futuro da gestão do conhecimento mais além da estrutura. É, portanto, imperioso continuar com as pesquisas neste campo que possam levar em conta os impactos da prospectiva da gestão do conhecimento nas organizações.
Os estudos bibliométricos refletem um aumento da pesquisa no âmbito da gestão do conhecimento. A partir do estudo feito por Gaviria-Marina, Merigób e Baier-Fuentes (2019) foi identificada a relevância que tem recebido o assunto nos últimos 10 anos, além do mais, os pesquisadores acharam que o país com maior influência no âmbito foi Estados Unidos. Outrossim, no estudo de Mardani, Nikoosokhan, Moradi e Doustarb (2018) foi comprovado que as atividades de gestão do conhecimento impactam diretamente a inovação e 0 desempenho, e indiretamente através do aumento da capacidade de inovação. A criação do conhecimento atinge significativamente a velocidade, qualidade e a quantidade de inovação, enquanto a qualidade da inovação a criação do conhecimento e a integração do conhecimento têm efeitos ainda mais significativos no desempenho organizacional.

$\mathrm{Na}$ atualidade fala-se de que o conhecimento é o principal ativo das organizações e os sistemas de gestão do conhecimento são implementados para um adequado gerenciamento deste recurso, no entanto, uma crítica à inovação na gestão do conhecimento é o foco nos aspectos técnicos e estruturais para a armazenagem do conhecimento e a pouca atenção na motivação das pessoas para a troca de tal conhecimento (Friedricha, Beckera, Kramerb, Wirthb y Schneider, s.f; Shujahat, Sousa, Hussain, Nawaz, Wang e Umer, 2019) e na prospectiva da gestão do conhecimento e suas dimensões (Bootz, Durance e Monti 2019). A esse respeito, a norma técnica ISO 30401 enfatiza a cultura para a gestão do conhecimento em todos seus estágios, como um componente inovador e diferenciador.

Alguns dos estudos relatados na literatura académica são orientados a apresentar planos de sistemas de gestão do conhecimento voltados à estratégia empresarial que suporta a sobrevivência, viabilidade e melhoria do processo de tomada de decisões de gestão no longo prazo, 
baseado no conhecimento e as experiências (Córdova, F. e Gutiérrez, 2018; Chouikha, M. e Dhaou, S, 2018).

É de salientar que 0 acesso ao conhecimento cria as oportunidades para o desenvolvimento profissional nas organizações através do aprendizado, da prática e da troca do conhecimento. Neste sentido, a pesquisa deve ser orientada não apenas a desenvolver estrutura para a gestão, mas também para a apropriação e empoderamento das pessoas que fazem parte de uma organização em prol da autogestão do conhecimento e a sua disposição para a criação de valor e do desenvolvimento organizacional.

Nesta perspectiva, a Revista SIGNOS-investigación en sistemas de gestión - foi criada para divulgar o conhecimento resultante de processos de pesquisa voltados à compreensão da interação dos sistemas de gestão em várias organizações e a sua contribuição para o conhecimento organizacional. Nesta ocasião, apresenta o número 11.2 que descreve os resultados de 10 pesquisas, nomeadamente:

1. As competências científicas a partir da gestão do conhecimento nas Instituições de Ensino Superior.

2. Qualidade de vida no trabalho para trabalhadores da saúde nos países latino-americanos: meta-análise.

3. Evolução do Relatório de Sustentabilidade na América Latina sob as diretrizes do GRI (Global Reporting Initiative).

4. Metodologia para a integração da gestão em uma PME do setor de ferragens na Colômbia a partir dos modelos SG-SST e ISO 9001.
5. Estratégias para o fortalecimento do processo de gestão do talento humano do sistema de gestão da qualidade em uma entidade pública.

6. União entre a NTC - ISO 9001:2015 e as diretrizes de credenciamento de programas do CNA em Unitrópico.

7. Integração da gestão da qualidade com as boas práticas de manufatura, suportado na gestão do risco e do conhecimento em três empresas farmacêuticas de soluções injetáveis em Bogotá, D.C.

8. Modelo de organização comunitária e desenvolvimento sustentável em Ixtlán de Juarez, Oaxaca.

9. Avaliação dos processos da área financeira e a sua harmonização com o sistema de gestão da qualidade baseado no modelo PEF em uma Instituição de Ensino Superior.

10. Análise bibliométrico da Revista SIGNOS-investigación en sistemas de gestión - período 1996/2016.

Os avanços nas pesquisas que foram descritos e as contribuições das revisões apresentadas fornecem uma aproximação dos componentes teórico-conceituais e da práxis na compreensão dos de aspectos associados à gestão do conhecimento nas organizações e cenários analisados, portanto, este número da revista é um referente para profissionais especializados, consultores, auditores, formadores empresariais, pesquisadores e professores universitários interessados em compreender os sistemas de gestão do conhecimento. 


\section{REFERÊNCIAS:}

Bootz, JP., Durance, P. y Monti, R. (2019). Foresight and knowledge management. New developments in theory and practice. Technological Forecasting and Social Change, 140, 80-83. https://doi.org/10.1016/j. techfore.2018.12.017

Chouikha, M. y Dhaou, S. (2018). A Multi-Faceted Analysis of Knowledge Management Systems, Procedia Computer Science, 138, 646-654. https://doi. org/10.1016/j.procs.2018.10.086

Córdova, F. y Gutiérrez, F. (2018). Knowledge Management System in Service Companies, Procedia Computer Science, 139, 392-400. https://doi.org/10.1016/j. procs.2018.10.275

Friedricha, J., Beckera, M., Kramerb, F., Wirthb, M., Schneider, M. (s.f). Incentive design and gamification for knowledge management. Journal of Business Research. Article in press.

Gaviria-Marina, M., Merigób, J., Baier-Fuentes, H. (2019). Knowledge management: A global examination based on bibliometric analysis. $T e$ chnological Forecasting and Social Change, 140, 194220. https://doi.org/10.1016/j.techfore.2018.07.006

International Organization for Standardiæation, -ISO. (2018). ISO 30401:2018. Knowledge management systems - Requirements. Ginebra: ISO.

Mardani, A., Nikoosokhan, S., Moradi, M. y Doustarb, M. (2018). The Relationship Between Knowledge Management and Innovation Performance. The Journal of High Technology Management Research, 29 (1), 12-26. https://doi.org/10.1016/j.hitech.2018.04.002

Shujahat, M., Sousa, M., Hussain, S., Nawaz, F., Wang, M. y Umer, M. (2019). Translating the impact of knowledge management processes into knowledge-based innovation: The neglected and mediating role of knowledge-worker productivity, Journal of Business Research, 94, 442-450. https://doi.org/10.1016/j.jbusres.2017.11.001. 